\title{
The Effect of Bilirubin on the Function of Hamster Small Intestine
}

\author{
PETER F. WHITINGTON, ${ }^{(36)}$ WARD A. OLSEN, AND GERARD B. ODELL \\ Department of Pediatrics, University of Tennessee Center for the Health Sciences, Memphis, Tennessee, and \\ Departments of Pediatrics and Medicine, University of Wisconsin School of Medicine, and W. S. Middleton Veterans \\ Administration Hospital, Madison, Wisconsin, USA
}

\begin{abstract}
Summary
Jaundice phototherapy is associated with a significant incidence of watery diarrhea. We have postulated that acute intestinal secretion, rather than malabsorption of dietary carbohydrate, is an effect of a photoproduct of bilirubin upon the intestinal mucosa. Because a major effect of phototherapy is the hepatic excretion of nonconjugated bilirubin, we investigated the effect of bilirubin on small intestinal function in the hamster in vivo.

The entire small intestine was luminally perfused in vivo with solutions containing bilirubin ( 0.125 to 0.75 mmole/liter) and net water and sodium fluxes were measured. Control animals absorbed both water $\left(J_{\text {net }}^{\mathrm{H}_{2} \mathrm{O}}=58.9 \mu \mathrm{l} / \mathrm{min} / \mathrm{g}\right)$ and $\operatorname{sodium}\left(\mathrm{J}_{\text {net }}^{\mathrm{Na}}=4.55 \mu \mathrm{Eq} /\right.$ $\mathrm{min} / \mathrm{g})$, but animals perfused with bilirubin $(\geq 0.25 \mathrm{mmole} / \mathrm{liter})$ exhibited secretion of water $\left(\mathrm{J}_{\text {net }}^{\mathrm{H}_{2} \mathrm{O}}=-39.0--85.9\right)$ and sodium $\left(J_{\text {net }}^{\mathrm{Na}}=-9.91--18.24\right)$. The rate of water secretion was positively related to the concentration of bilirubin in the infusate $(r=0.749$; $P<0.001)$. The concentration of bilirubin in ultrafiltrates of perfusate was likewise positively related to its concentration in the infusate $(r=0.844 ; P<0.001)$, indicating the potential importance of soluble forms of bilirubin in inducing secretion. Possible epithelial injury was studied by measuring the concentration of DNA in the perfusate and the activity of disaccharidases in postperfusion mucosa, and the possible role of cyclic adenosine monophosphate as a mediator of the secretory process was investigated by determining its concentration in postperfusion mucosa. Perfusion with $0.5 \mathrm{mM}$ bilirubin, which produced significant secretion, did not cause loss of DNA (0.284 versus $0.244 \mathrm{mg} /$ liter $)$ or mucosal lactase activity (56 versus 53 units/g) or enhancement of cyclic adenosine monophosphate concentration (14.9 versus 14.12 pmoles/mg protein).
\end{abstract}

\section{Speculation}

These data seem consistent with the hypothesis that jaundice phototherapy causes watery diarrhea by enhancing the hepatic excretion of nonconjugated bilirubin, which, in turn, causes intestinal secretion.

A recent survey has estimated that $10 \%$ of infants born in the United States receive phototherapy for neonatal jaundice (16). Such therapy is associated with a significant $(9.5 \%)$ incidence of watery diarrhea (19), characterized by increased fecal water loss (26) and decreased gut transit time (29). The pathogenesis of this diarrhea has not been established, but a photoproduct of bilirubin is presumed to be involved in the mechanism because both light and hyperbilirubinemia are required for its development (29). Although intestinal lactase deficiency has been found in affected infants (1), recent data indicate that lactose intolerance cannot be demonstrated in these infants $(13,14)$. We have observed diarrhea to develop within a few hours of light exposure and in the absence of oral intake. These observations lead us to postulate that acute intestinal secretion, rather than malabsorption of dietary carbohydrate, is an effect of a photoproduct of bilirubin.

Phototherapy induces hepatic excretion of nonconjugated bilirubin through a postulated mechanism involving configurational isomerization of bilirubin, Z-Z bilirubin IX $\alpha$, to "photobilirubin," composed of the two Z-E and the E-E bilirubin IX $\alpha$ configurational isomers, a pigment which is readily excreted by the liver. The kinetics of reversion of photobilirubin to bilirubin have not been elucidated, but the Z-E isomers are presumably unstable and revert to $Z-Z$ bilirubin within the biliary tract or the gut $(6,20,24$, 27). Overall, a major effect of phototherapy is the hepatic excretion of nonconjugated bilirubin into the gut.

We have tested the possibility that bilirubin causes intestinal secretion by measuring the effects of bilirubin on the small intestinal function of hamsters. The results indicate that bilirubin itself can induce intestinal secretion and suggest that the watery diarrhea often witnessed in jaundiced infants treated by phototherapy may be a consequence of the high concentrations of bilirubin within the intestinal lumen.

\section{MATERIALS AND METHODS}

\section{PERFUSION TECHNIQUE}

Fed, male Syrian golden hamsters (Sprague-Dawley, Madison, WI) weighing between 80 and $110 \mathrm{~g}$ were anesthetized with $10 \mathrm{mg}$ of intraperitoneal pentobarbital sodium, the abdomen was opened in the midline, and the bowel was ligated just distal to the entry of the common bile duct and at the ileocecal junction. Incisions were made in the duodenum and in the distal ileum, and the small bowel was irrigated was $10 \mathrm{ml}$ of warm $0.9 \% \mathrm{NaCl}$ solution. Polyvinyl chloride cannulae were secured at the ligament of Treitz and in the distal ileum for purposes of infusion and collection of fluid. Perfusion flow was controlled at 0.73 to $0.83 \mathrm{ml} / \mathrm{min}$, determined gravimetrically before each animal perfusion by a four-channel peristaltic pump. All perfusions were performed in dim tungsten lighting, and the perfusion solutions were maintained at $37^{\circ} \mathrm{C}$ in the dark.

Because bilirubin is sparingly soluble at physiologic $\mathrm{pH}(2,28)$, a neutralization technique was used to deliver pigment to the bowel. Infusates consisted of two solutions, an alkaline solution (A), $70 \mathrm{mM} \mathrm{NaCl}$ and $42 \mathrm{mM} \mathrm{Na} \mathrm{CO}_{3}$, in which bilirubin was readily dissolved, and an acid solution (B), $154 \mathrm{mM} \mathrm{NaCl}$ and 42 $\mathrm{mM} \mathrm{HCl}$. The solutions were pumped at identical rates on two channels of the pump in tubes A and B. Tube A penetrated tube $B$, and the catheters terminated simultaneously so that mixing of the solutions occurred upon entry into the bowel. The mixture of $\mathrm{CO}_{3}{ }^{=}$and $\mathrm{H}^{+}$produced a physiologic perfusate containing $21 \mathrm{mM}$ $\mathrm{HCO}_{3}{ }^{-}$.

Crystalline bilirubin, obtained from Sigma Chemical Co. (St. Louis, MO) (Lot 104C-0144) was dissolved in solution A. The final concentration of bilirubin in the infusates was 0.125 to 0.75 
mmole/liter; although the solubility of bilirubin was clearly exceeded, concentrations are expressed as $\mathrm{mM}$. The bilirubin contained greater than $99 \%$ IX $\alpha$-isomer by thin-layer chromatography (23), and the infusate contained no bile salts as determined by a $3 \alpha$-steroid dehydrogenase method sensitive to $1 \mathrm{nmole} / \mathrm{ml}$ (15).

The adequacy of mixing of the perfusate within the lumen and the control of luminal $\mathrm{pH}$ in the perfused animal were of concern. To investigate these potential problems, two groups of animals, a control group and one receiving $0.5 \mathrm{mM}$ bilirubin, were perfused for $30 \mathrm{~min}$, and perfusate was rapidly and sequentially obtained from $20,10,5$, and $1 \mathrm{~cm}$ distal to the infusate site. The bowel was punctured with a 23 gauge scalp vein needle, and fluid $(0.4 \mathrm{ml})$ was collected by gravity-assisted flow. The $\mathrm{PCO}_{2}$ and $\mathrm{pH}$ of perfusate retained within the scalp vein apparatus were immediately determined by micro blood gas analyzer (Instrumentation Laboratory Micro 13). The osmolality of the collected fluid was measured by freezing point depression (Osmette S., Precision Systems), and the total $\mathrm{CO}_{2}$ content was determined by Van Slyke (Natelson Microgasometer model 600). Blood was obtained from the inferior vena cava, and serum osmolality was determined at the termination of the perfusion in both groups.

\section{MEASUREMENT OF NET WATER AND SODIUM FLUX}

Net water flux was determined using a nonabsorbable marker, polyethylene glycol (4000 mw) (PEG), in the perfusion solution. Solutions contained $2 \mu \mathrm{Ci}$ of $\left[{ }^{14} \mathrm{C}\right] \mathrm{PEG}$ and $0.5 \mathrm{~g}$ PEG per $100 \mathrm{ml}$. The first $30 \mathrm{~min}$ of perfusate was discarded, and perfusate was collected for three succeeding 20 -min periods. At the end of the collection period, the small bowel was removed and dried to constant weight at $100^{\circ} \mathrm{C}$. Perfusates were centrifuged at $1000 \times$ $g$ for $10 \mathrm{~min}$, and $2 \mathrm{ml}$ of the supernatant were decolorized by the addition of $20 \mu \mathrm{l}$ commercial laundry bleach to reduce scintillation quenching. Duplicate $200 \mu \mathrm{l}$ aliquots were mixed with $3.0 \mathrm{ml}$ of water miscible scintillation fluid (Aquasol; New England Nuclear, Boston, MA) and were counted for ${ }^{14} \mathrm{C}$ in liquid scintillation spectrometer (Packard Tri-carb 3255) with an efficiency of 70 to $85 \%$. Counts were corrected to dpm by inclusion of an external standard. Sodium concentrations were measured by flame photometry (Instrumentation Laboratory model 343), and $\mathrm{Cl}^{-}$concentrations were determined in a chloride analyzer (Beckman model 015-083993).

Net water flux, expressed as $\mu \mathrm{l} / \mathrm{min} / \mathrm{g}$ dry bowel, and net sodium flux, expressed as $\mu \mathrm{Eq} / \mathrm{min} / \mathrm{g}$, were calculated for each of the three 20 -min perfusion periods by standard formulae (5). Net flux for the total 60 min perfusion period was computed as the arithmetic mean of those calculated for the three individual 20 min collection periods.

Marker $\left(\left[{ }^{14} \mathrm{C}\right] \mathrm{PEG}\right)$ recovery was determined in six control and six experimental animals ( $0.5 \mathrm{mM}$ bilirubin). Total effluent volume over $60 \mathrm{~min}$ was determined gravimetrically. The total ${ }^{14} \mathrm{C}$ recovery (the product of the perfusate ${ }^{14} \mathrm{C}$ and volume), when expressed as a percentage of the ${ }^{14} \mathrm{C}$ infused (the product of the infusate ${ }^{14} \mathrm{C}$, flow rate, and time) was $100.10 \pm 2.72$ (S.D.) $\%$, control, and $100.19 \pm 2.41$, experimental.

BIOCHEMICAL ASSESSMENT OF MUCOSAL DAMAGE AND MEASUREMENT OF CYCLIC ADENOSINE MONOPHOSPHATE (CAMP)

Hamsters were perfused for 90 min with control solutions or 0.5 $\mathrm{mM}$ bilirubin in these experiments.

The concentration of DNA in the perfusate was used as a measure of the rate of cellular loss into the gut lumen (5). Perfusate was collected in $50 \mathrm{ml}$ centrifuge tubes maintained on ice containing $0.5 \mathrm{ml}$ of $0.3 \mathrm{M}$ EDTA, $\mathrm{pH} 8.0$, and analyzed for DNA by the method of Croft and Lubran (10). Results are expressed as mg DNA per liter.

Epithelial brush border damage was quantitated by measurement of the activities of mucosal lactase and sucrase. The bowel was removed immediately upon termination of the perfusion and was placed in cold $0.9 \% \mathrm{NaCl}$ solution. Mucosa, scraped from inverted bowel, was weighed, diluted $1: 100 \mathrm{w} / \mathrm{v}$ with $0.9 \%$ saline solution, and homogenized in a Waring blender for $30 \mathrm{sec}$. $\mathrm{Mu}-$ cosal homogenates were stored at $-20^{\circ}$ until analyzed for lactase and sucrase activity by the method of Dahlqvist (11). Enzyme activity was measured in all samples simultaneously and within 2 wk of collection. The results are expressed as $\mu$ moles glucose liberated per min per $g$ protein of mucosal homogenate (units/g). Protein was measured by a modification of the method of Lowry (32) using bovine serum albumin as the reference standard.

The concentration of cAMP in mucosa after perfusion was measured to investigate its role as an intermediate in the secretory process. Bowel, removed immediately after perfusion, was rinsed with an iced solution of $8 \mathrm{mM}$ theophylline in $0.1 \mathrm{M}$ Tris $(\mathrm{pH}$ 7.4). The mucosa was scraped free, and the mucosal proteins were precipitated by homogenizing in $5.0 \mathrm{ml}$ of $6 \%$ trichloroacetic acid at $4^{\circ} \mathrm{C}$. cAMP concentrations were determined by radioimmunoassay (New England Nuclear CAMP ${ }^{125}$ I RIA Kit) and expressed as $\mathrm{pmoles} / \mathrm{mg}$ protein.

\section{DETERMINATION OF THE PHYSICAL STATE OF BILIRUBIN IN THE PERFUSATE}

The amount of soluble bilirubin in the luminal fluid was quantitated to help to explain the observation that increases in the infusate concentration produced increasing secretory effects. Perfusate was collected from the ileal cannula without exposure to air and was centrifuged at $3000 \times g$ for $30 \mathrm{~min}$. The supernatant was centrifuged at $20,000 \times g$ for $1 \mathrm{hr}$. Total bilirubin concentrations in perfusate and in both supernatants were determined.

Because the acid of the bicarbonate buffer system is volatile, difficulty was encountered in maintaining the $\mathrm{pH}$ of the aspirated perfusates during centrifugation. Ultrafiltration of the perfusates under controlled concentrations of gaseous $\mathrm{CO}_{2}$ was subsequently used. Concentrations of $0.25,0.5$, or $0.75 \mathrm{mM}$ bilirubin were infused in these experiments. After $30 \mathrm{~min}$ of perfusion, the bowel was gently cannulated sequentially at 20,10 , and $1 \mathrm{~cm}$ from the infusion site. Six ml of perfusate were collected in a tube gassed with $5 \% \mathrm{CO}_{2}: 95 \% \mathrm{O}_{2}$. The $\mathrm{PCO}_{2}$ and $\mathrm{pH}$ of the fluid were determined, and the remaining fluid was passed through a previously gassed $0.25 \mu \mathrm{m}$ Millipore filter. The filtration pressure was provided by the above gas mixture. Spectral curves of filtrates of fluid from six animals demonstrated absorbance maximum at $440 \mathrm{~nm}$ and sharply declining shoulders, the curve of free aqueous bilirubin. Absorbance at $600 \mathrm{~nm}$ was also recorded in the ultrafiltrates and used as a measure of light scattering. Conjugated bilirubin was determined by reacting with diazotized ethyl anthranilate (18). Total bilirubin concentrations in the infusates and perfusates were measured by the method of Malloy and Evelyn (22); diazotized $p$-iodoaniline (18) was used to determine bilirubin concentration in those fluids containing less than $17 \mu \mathrm{m}$ bilirubin.

\section{STATISTICAL ANALYSIS}

Differences between means of grouped data were analyzed by Student's $t$ test, and the $t$ test for paired samples was used for comparison of within group data.

\section{RESULTS}

\section{PERFUSION TECHNIQUE}

$\mathrm{PCO}_{2}, \mathrm{pH}$, and total $\mathrm{CO}_{2}$ content were determined at several positions along the length of perfused intestine (Table 1). No differences were found between experimental and corresponding control values, and the data demonstrate that the system of perfusion is physiologic with respect to acid-base characteristics.

The electrolyte content of infusates and perfusates was measured in a control group $(n=8)$ and in an experimental group ( $n$ $=7)$. The perfusion system accurately delivered physiologic con- 
Table 1. $\mathrm{PCO}_{2}, p H$, and total $\mathrm{CO}_{2}$ content of perfusate obtained at various distances from the site of infusion in a control group $(n=11)$ and an experimental ( $0.5 \mathrm{mM}$ bilirubin) group $(n=9)$

Distance from site of infusion $(\mathrm{cm})$

\begin{tabular}{|c|c|c|c|c|}
\hline & \multicolumn{4}{|c|}{ Distance from site of infusion $(\mathrm{cm})$} \\
\hline \multicolumn{5}{|l|}{ Control } \\
\hline $\begin{array}{l}\mathrm{PCO}_{2} \text { (mm Hg) } \\
\mathrm{pH} \text { (units) } \\
\mathrm{CO}_{2} \text { (mEq/liter) }\end{array}$ & $\begin{array}{l}38.9 \pm 25.0^{1} \\
7.46 \pm 0.37 \\
23.2 \pm 6.5\end{array}$ & $\begin{array}{l}31.2 \pm 16.7 \\
7.54 \pm 0.29 \\
22.9 \pm 3.5\end{array}$ & $\begin{array}{l}27.1 \pm 14.8 \\
7.59 \pm 0.27 \\
21.3 \pm 2.8\end{array}$ & $\begin{array}{l}23.6 \pm 9.3 \\
7.64 \pm 0.19 \\
22.8 \pm 2.1\end{array}$ \\
\hline $\begin{array}{l}\mathrm{PCO}_{2} \text { (mm Hg) } \\
\mathrm{pH} \text { (units) } \\
\mathrm{CO}_{2} \text { (mEq/liter) }\end{array}$ & $\begin{array}{l}47.0 \pm 17.4 \\
7.31 \pm 0.22 \\
21.4 \pm 5.4\end{array}$ & $\begin{array}{l}27.6 \pm 24.3 \\
7.69 \pm 0.45 \\
21.6 \pm 3.3\end{array}$ & $\begin{array}{l}28.7 \pm 19.9 \\
7.59 \pm 0.25 \\
22.8 \pm 3.2\end{array}$ & $\begin{array}{l}29.1 \pm 16.3 \\
7.56 \pm 0.20 \\
22.6 \pm 2.9\end{array}$ \\
\hline
\end{tabular}

${ }^{1} \overline{\mathrm{x}} \pm$ S.D.

centrations of $\mathrm{Na}^{+}$and $\mathrm{Cl}^{-}$to the intestine; no experimental value was different from the corresponding control value. In both animal groups, there was a slight increase in the concentration of $\mathrm{Na}^{+}$in the perfusate over the infusate: control, $153.3 \pm 0.6$ versus 151.8 $\pm 1.1 \mathrm{mEq} /$ liter, $P<0.01$; experimental, $152.3 \pm 1.0$ versus 150.9 $\pm 1.2 \mathrm{mEq} /$ liter, $P<0.01$. Chloride concentration was slightly lower in perfusates than in infusates of control (129.6 \pm 3.6 versus $131.6 \pm 1.8 \mathrm{mEq} /$ liter, $P>0.10)$ and experimental animals $(131.1$ \pm 1.7 versus $133.4 \pm 3.1 \mathrm{mEq} / \mathrm{liter}, P<0.10$ ).

The osmolalities of the infusates and perfusates obtained from several positions along the intestinal length are given in Figure 1. Control values were not different from the corresponding experimental ones. The osmolality of the aspirates increased with distance from the site of infusion in both groups. Serum osmolality was measured in nine hamsters and was $344 \pm 12 \mathrm{mOsm} / \mathrm{kg}$. The increasing osmolality of the perfusates from both groups presumably resulted from water moving down an osmotic gradient and is consistent with the current hypothesis that water movement in the small intestine is passive following osmotic or activity gradients.

\section{NET WATER AND SODIUM FLUXES}

Inclusion of bilirubin in the infusate altered net water and sodium fluxes (Table 2). Control animals exhibited positive net flux (absorption) of both water and sodium. Animals which were perfused with 0.25 to $0.75 \mathrm{mM}$ bilirubin had secretion (negative net flux) of both water and sodium. Significant negative correlations of net water flux $(r=-0.749 ; P<0.001)$ and net sodium flux $(r=-0.732 ; P<0.001)$ with increasing concentrations of bilirubin in the infusate were demonstrated. Of interest was the apparent discrepancy between water and sodium flux which was most easily seen in animals perfused with $0.125 \mathrm{mM}$ bilirubin; a simple calculation demonstrated that in all groups there was a constant absorption of water in excess of sodium or secretion of sodium in excess water. This finding was consistent with passive water movement down an osmotic gradient as noted above. Water presumably passively followed sodium, either absorbed or secreted, and at the same time moved down the osmotic gradient existent from lumen to serosa.

The time course of water flux was examined for evidence of decay in the rate absorption or of cumulative bilirubin toxicity (Fig. 2). No difference was found in net water flux for any time period within animal groups, illustrating stability and lack of cumulative dose effect.

\section{BIOCHEMICAL ASSESSMENT OF MUCOSAL INTEGRITY AND MEASUREMENT OF MUCOSAL (CAMP)}

Mucosal lactase and sucrase activities were not different in 12 control from 12 experimental animals. The values for sucrase are

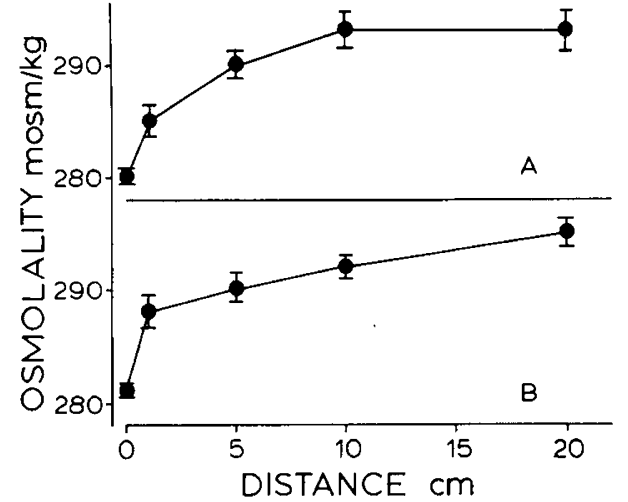

Fig. 1. The osmolalities $(\bar{x} \pm$ S.E.) of the luminal perfusate as a function of length (distance from the infusion site) of perfused bowel in experimental $(A, 0.50 \mathrm{mM}$ bilirubin; $n=9)$ and control $(B, n=11)$ animals are illustrated. The osmolality of perfusate from all positions was higher $(P<0.01)$ than that of the infusate.

for control: $142 \pm 31$ (S.D.) units/g; and experimental: $171 \pm 35$; lactase values are for control: $53 \pm 9$; and experimental: $56 \pm 9$.

The loss of DNA into the lumen was not different in experimental from control animals; the DNA concentration in the perfusate from five control animals was $0.244 \pm 0.158$ (S.D.) $\mathrm{mg}$ / liter and in five experimentals was $0.284 \pm 0.163 \mathrm{mg} /$ liter.

Table 3 illustrates the mucosal cAMP concentrations measured after perfusion with $0.5 \mathrm{mM}$ bilirubin, $4 \mathrm{mM}$ ricinoleate, $10 \mathrm{mM}$ deoxycholate (all of which produce secretion in the hamster), and $10 \mathrm{mM}$ taurocholate (which does not cause secretion) $(5,17)$. In contrast to ricinoleate and deoxycholate, perfusion with bilirubin did not result in enhancement of mucosal cAMP concentration.

\section{DETERMINATION OF THE PHYSICAL STATE OF BILIRUBIN IN THE PERFUSATE}

Experiments $(n=3)$ using centrifugation to elucidate the physical state of bilirubin in the perfusate demonstrated that the total concentration of bilirubin in perfusate collected from the ileal cannula averaged $50 \%$ of the infused concentration. Presumably the concentration was reduced through absorption, precipitation, adsorption, and, to a lesser degree, dilution. Some of the bilirubin formed flocculent precipitates which could be sedimented at low centrifugal force $(3000 \times g$ for $30 \mathrm{~min}$ ), but $78 \%$ remained in suspension despite centrifugation at $20,000 \times g$ for $1 \mathrm{hr}$. The $20,000 \times g$ supernatants uniformly also exhibited absorbances at $600 \mathrm{~nm}>2.0$, indicative of microaggregates of bilirubin that were not sedimented. 
Table 2. Net water flux and net sodium flux measured with increasing concentration of bilirubin in the infusate

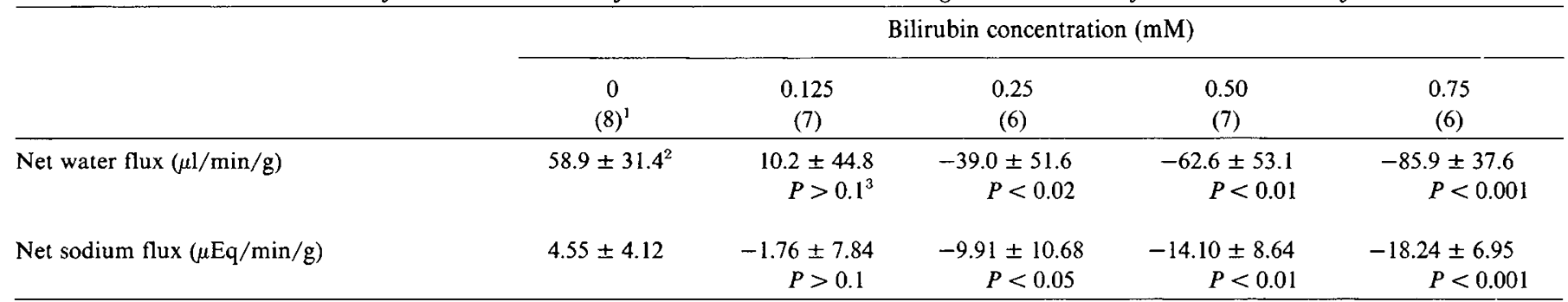

\footnotetext{
' Numbers in parentheses, number of animals tested.

${ }^{2} \bar{x} \pm$ S.D.

${ }^{3}$ As compared to control value.
}

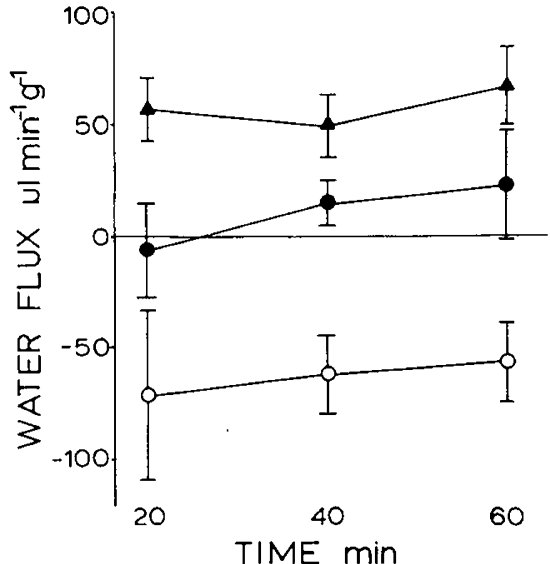

Fig. 2. Net water fluxes $(\bar{x} \pm$ S.E. $)$ of control animals $(\Delta ; n=8)$ and animals perfused with solutions containing bilirubin $(0.125 \mathrm{mM}(\mathbf{\theta} ; n=7)$ and $0.5 \mathrm{mM}(\mathrm{O} ; n=7))$ are shown as functions of the duration of perfusion. The first $30 \mathrm{~min}$ of perfusate was discarded, and net water fluxes were determined during three succeeding 20 -min periods.

Ultrafiltration of perfusate obtained from three areas of the intestine $(1,10$, and $20 \mathrm{~cm}$ distal to the infusion site) during infusion with three concentrations of bilirubin $(0.25,0.50$, and $0.75 \mathrm{mM}$ ) demonstrated a stepwise increase in the concentration of bilirubin in the ultrafiltrate with increasing infusion concentration (Fig. 3). Thus, increasing the amount of bilirubin in the infusate resulted in increases in the luminal concentration of soluble, monomeric, or oligomeric bilirubin. However, there was considerable overlap between groups. A declining concentration of soluble bilirubin with increasing distance from the perfusion site was also evident (Fig. 3).

The linear regression of the absorbance at $440 \mathrm{~nm}(\mathrm{y})$ versus $\mathrm{mM}$ bilirubin concentration $(\mathrm{x})$ in the ultrafiltrates, $\mathrm{y}=165.9 \mathrm{x}+$ 0.50 , demonstrated a high degree of correlation $(r=0.927)$ between the two measurements. No ultrafiltrate contained measurable amounts of conjugated bilirubin, and the absorbance at 600 $\mathrm{nm}$ never exceeded 0.010 , indicating the absence of aggregates of bilirubin or of biliverdin (34) in the filtrates.

The $\mathrm{pH}$ and $\mathrm{PCO}_{2}$ of the perfusates gassed during collection for these experiments were similar to those collected in a closed system. The range of the mean $\mathrm{pH}$ values for all nine groups (three positions $\times$ three concentrations) was 7.48 to 7.68 .

\section{DISCUSSION}

These studies were conducted to explain the occurrence of acute diarrhea that occurs in some newborn infants treated with phototherapy for neonatal jaundice. We elected to study the effect of bilirubin on intestinal function because bilirubin is a major excre- tory product of phototherapy $(6,27)$. Lund and Jacobsen (21) measured the concentration of nonconjugated bilirubin in the duodenal bile of seven infants during phototherapy and found a mean concentration of $0.047 \mathrm{mM}$. However, one of the seven had a concentration of $0.127 \mathrm{mM}$ which is equivalent to the lowest concentration $(0.125 \mathrm{mM})$ tested in this study. This test group as a whole exhibited net absorption of water (Table 2), but three of seven experimental animals and zero of eight control animals demonstrated net secretion $\left(\chi^{2}=4.28 ; P<0.05\right)$. Extrapolation from these numbers indicates that excretion of bilirubin at this or greater concentrations during phototherapy could account for the diarrhea which occurs in affected infants.

Perfusion was performed in such a way that bilirubin in the bowel lumen would undergo transition from a solution to a complex mixture, comprising colloidal, oligomeric, and monomeric forms, at physiologic $\mathrm{pH}$ (3). This system may have analogies to that existent in infants treated with phototherapy. During phototherapy bile contains photobilirubin (25), which is apparently water soluble (2), aqueous bilirubin in solution at alkaline $\mathrm{pH}$, and bilirubin solubilized by incorporation into mixed micelles and by self-aggregation $(4,30)$. Within the duodenum, the following occur: bilirubin results from spontaneous configurational isomerization of photobilirubin; the $\mathrm{pH}$ falls; and because newborn infants frequently have less than micellar concentrations of bile salts, the micellar sink is lost $(31,33)$. This is a unique circumstance wherein significant concentrations of free nonconjugated bilirubin might occur in the intestinal lumen.

The perfusion data demonstrate that bilirubin induces secretion by hamster small intestine and is more powerful in this regard than are deoxycholate and ricinoleate $(5,17)$. The mechanism by which bilirubin induces secretion is not elucidated. It does not appear to induce AMP production (Table 3) or cause enterocyte damage as indicated by the normal brush border disaccharidase activity and the absence of DNA loss in the perfusates. These latter mechanisms seem important for surfactant induced secretion $(9,17)$.

Extensive investigation of the neurotoxicity of bilirubin has shown that when free to enter cells it disrupts energy metabolism $(7,8,35)$. Potentially, such an effect on absorptive cells could account for apparent secretion by interfering with normal absorption in acute experiments such as these.

Implicit in the observation that bilirubin induces intestinal secretion is delivery of bilirubin to the intestinal epithelium. Because the unstirred water layer would represent a significant diffusion barrier to colloidal bilirubin (12), the secretion rate may be related to the concentration of soluble bilirubin in these experiments. The current results demonstrate increased rates of secretion and stepwise increases in soluble bilimbin in ultrafiltrates of perfusate as bilirubin concentrations in the infusate are increased. Thus, even though the bilirubin concentrations in the infusates exceed its aqueous solubility at the $\mathrm{pH}$ of intestinal fluid, significant $(1$ or $2 \mu \mathrm{M})$ concentrations of ultrafilterable bilirubin are present in the perfusate throughout the perfused intestine (Fig. 3); 
Table 3. CAMP concentrations in hamster intestinal mucosa after perfusion with control solution, bilirubin, and a variety of anionic surfactants

\begin{tabular}{|c|c|c|c|c|c|}
\hline & $\begin{array}{c}\text { Control } \\
(10)^{1} \\
\end{array}$ & $\begin{array}{c}\text { Bilirubin } \\
(0.5 \mathrm{mM}) \\
(10)\end{array}$ & $\begin{array}{c}\text { Ricinoleate } \\
(4 \mathrm{mM}) \\
(5)\end{array}$ & $\begin{array}{c}\text { Deoxycholate } \\
(10 \mathrm{mM}) \\
(5)\end{array}$ & $\begin{array}{c}\text { Taurocholate } \\
(10 \mathrm{mM}) \\
(4)\end{array}$ \\
\hline cAMP (pmoles/mg protein) & $14.12 \pm 7.77^{2}$ & $\begin{array}{c}14.91 \pm 6.85 \\
P>0.8^{3}\end{array}$ & $\begin{array}{c}37.68 \pm 18.27 \\
P<0.05\end{array}$ & $\begin{array}{c}31.73 \pm 12.70 \\
P<0.05\end{array}$ & $\begin{array}{c}13.13 \pm 3.22 \\
P>0.7\end{array}$ \\
\hline
\end{tabular}

${ }^{1}$ Numbers in parentheses, number of animals tested.

${ }^{2} \bar{x} \pm$ S.D.

${ }^{3}$ As compared to control value.

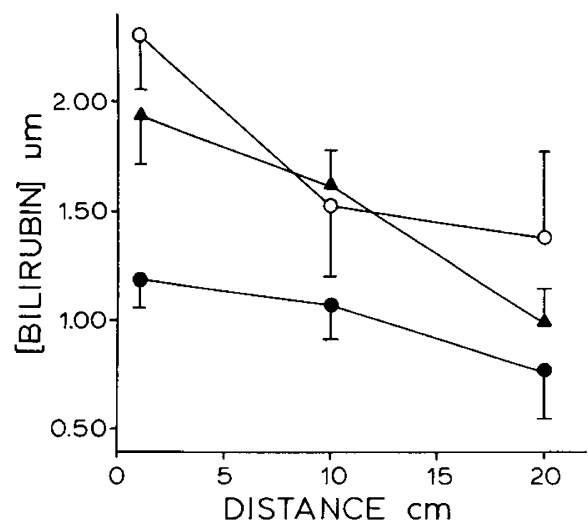

Fig. 3. The concentration of bilirubin in ultrafiltrates of luminal perfusate $(\bar{x} \pm$ S.E.) is shown as a function of length (distance from the infusion site) of perfused bowel and as a function of the concentration of bilirubin in the infusate $(0.75 \mathrm{mM}(\bigcirc) ; 0.50 \mathrm{mM}(\Delta) ; 0.25 \mathrm{mM}(\Theta) ; n=6$ at each concentration). A highly significant correlation existed between the concentration of bilirubin in the infusate and that in ultrafiltrates of perfusate obtained both proximally $(1 \mathrm{~cm} ; r=0.844 ; P<0.001)$ and distally $(20 \mathrm{~cm} ; r=0.602 ; P<0.0 \mathrm{l})$.

potentially, a soluble fraction of the infused bilirubin results in alteration of intestinal function.

Bilirubin concentrations in duodenal bile obtained from human neonates during jaundice phototherapy also exceed its aqueous solubility (21). Data regarding the physical state of this bilirubin and the amount of bilirubin which may have already entered the intestinal mucosa are lacking. Not withstanding the possible confounding effects of other photoproducts of bilirubin (6) on intestinal function and the possible effects of luminal bile salts and phospholipids on the solubility of nonconjugated bilirubin (30), free nonconjugated bilirubin potentially results in intestinal secretion in these infants.

\section{REFERENCES AND NOTES}

1. Bakken, A. F.: Temporary intestinal lactase deficiency in light-treated jaundiced infants. Acta Paediatr. Scand., 66: 91 (1977).

2. Broderson, R.: Bilirubin: solubility and interaction with albumin and phospholipid. J. Biol. Chem., 254: 2364 (1979).

3. Broderson, R., and Theilgaard, J.: Bilirubin colloid formation in neutral aqueous solution. Scand. J. Clin. Lab. Invest., 24: 395 (1969).

4. Carey, M. C., and Koretsky, A. P.: Self-association of unconjugated bilirubinIX $\alpha$ in aqueous solution at $\mathrm{pH} 10.0$ and physical-chemical interaction with bile salt monomers and micelles. Biochem. J., 179: 675 (1979).

5. Cline, W. S., Lorenzsonn, V., Benz, L., Bass, P., and Olsen, W. A.: The effects of sodium ricinoleate on small intestinal function and structure. J. Clin. Invest., 58: 380 (1976).

6. Cohen, A. N., and Ostrow, J. D.: New concepts in phototherapy: photoisomerization of bilirubin IX $\alpha$ and potential toxic effects of light. Pediatrics, 65: 740 (1980).

7. Cowger, M. L.: Mechanism of bilirubin toxicity on tissue culture cells: factors that affect toxicity, reversibility by albumin, and comparison with other respiratory poisons and surfactants. Biochem. Med., 5: 1 (1971).

8. Cowger, M. L., Igo, R. P., and Labbe, R. F.: The mechanism of bilirubin toxicity studied with purified respiratory enzyme and tissue culture systems. Biochemistry, 4: 2763 (1965).

9. Coyne, M. J., Bonorris, G. G., Chung, A., Conley, D., and Schoenfield, L. J.: Propranolol inhibits bile acid and fatty acid stimulation of cyclic AMP in human colon. Gastroenterology, 73: 971 (1977).

10. Croft, D. N., and Lubran, M.: The estimation of deoxyribonucleic acid in the presence of sialic acid: application to analysis of human gastric washings. Biochem. J., 95: 612 (1965).

11. Dahlqvist, A.: Assay of intestinal disaccharidases. Anal. Biochem., 22: 99 (1968)

12. Dietschy, J. M., Sallee, L., and Wilson, F. A.: Unstirred water layers and absorption across the intestinal mucosa. Gastroenterology, 61: 932 (1971).

13. Ebbesen, F., Edelsten, D., and Hertel, J.: Gut transit time and lactose malabsorption during phototherapy: I. A study using lactose-free human mature milk. Acta Paediatr. Scand., 69: 65 (1980).

14. Ebbesen, F., Edelsten, D., and Hertel, J.: Gut transit time and lactose malabsorption during phototherapy: II. A study using raw milk from the mothers of the infants. Acta Paediatr. Scand., 69: 69 (1980).

15. Fausa, O.: Quantitative determination of serum bile acids using a purified $3 \alpha-$ hydroxysteroid dehydrogenase. Scand. J. Gastroenterol, 10: 747 (1975).

16. Final Report of the Committee on Phototherapy in the Newborn. Committee on Phototherapy in the Newborn, Division of Medical Sciences, Assembly of Life Sciences, National Research Council, National Academy of Sciences, Washington, D. C., 1974.

17. Gullikson, G. W., Cline, W. S., Lorenzsonn, V., Benz, L., Olsen, W. A., and Bass, P.: Effects of anionic surfactants on hamster small intestinal membrane structure and function: relationship to surface activity. Gastroenterology, 73: 501 (1977).

18. Heirwegh, K., Fevery, J., Meuwissen, A., de Groote, J., Campernolle, F., Desmet, $V$., and van Roy, F.: Recent advances in the separation and analysis of diazopositive bile pigments. In: D. Glick: Methods of Biochemical Analysis. Vol. 22 p. 205 (John Wiley \& Sons, New York, 1974)

19. John, E.: Complications of phototherapy in neonatal hyperbilirubinemia. Aust. Paediatr. J., 11: 53 (1975).

20. Lightner, D. A., Wooldridge, T. A., and McDonagh, A. F.: Configurational isomerization of bilirubin and the mechanism of jaundice phototherapy. Biochem. Biophys. Res. Commun., 86: 235 (1979).

21. Lund, H. T., and Jacobsen, J.: Influence of phototherapy on unconjugated bilirubin in duodenal bile of newborn infants with hyperbilirubinemia. Acta Paediatr. Scand., 61: 693 (1972).

22. Malloy, H., and Evelyn, K.: The determination of bilirubin with the photoelectric colorimeter. J. Biol. Chem., 119: 481 (1937).

23. McDonagh, A. F., and Assisi, F.: Commercial bilirubin: a trinity of isomers FEBS Lett., 18: 315 (1971).

24. McDonagh, A. F., Lightner, D. A., and Wooldridge, T. A.: Geometric isomerization of bilirubin-IX $\alpha$ and its dimethyl ester. J.C.S. Chem. Comm., 1979: 110 (1979).

25. McDonagh, A. F., and Ramonas, L. M.: Jaundice phototherapy: micro flow-cell photometry reveals rapid biliary response of Gunn rats to light. Science (Wash. D. C.), 201: 829 (1978).

26. Oh, W., and Karecki, H.: Phototherapy and insensible water loss in the newborn infant. Am. J. Dis. Child., 124: 230 (1972).

27. Ostrow, J. D.: Photocatabolism of labeled bilirubin in the congenitally jaundiced (Gunn) rat. J. Clin. Invest., 50: 707 (1971).

28. Overbeek, J. T. G., Vink, C. L. J., and Deenstra, H.: The solubility of bilirubin. Recl. Trav. Chim. Pay-Bas Belg., 74: 81 (1955).

29. Rubaltelli, F. F., and Largajolli, G.: Effect of light exposure on gut transit time in jaundiced newborns. Acta Paediatr. Scand., 62: 146 (1973).

30. Scharschmidt, B. F., and Schmid, R.: The micellar sink: a quantitative assessment of the association of organic anions with mixed micelles and other macromolecular aggregates in rat bile. J. Clin. Invest., 62: 1122 (1978).

31. Signer, E., Murphy, G. M., Edkins, S., and Anderson, C. M.: Role of bile salts in fat malabsorption of premature infants. Arch. Dis. Child., 49: 174 (1974).

32. Sutherland, E. W., Cori, C. F., Haynes, R., and Olsen, N. S.: Purification of the hyperglycemic-glycogenolytic factor from insulin and from gastric mucosa. $J$. Biol. Chem., I80: 825 (1949).

33. Watkins, J. B., Ingall, D., Szczepanic, P., Klein, P. D., and Lester, R.: Bile salt metabolism in the newborn: measurement of pool size and synthesis by stable isotope technique. N. Engl. J. Med., 288: 431 (1973).

34. With, T. K.: In: Bile Pigments, p. 29 (Academic Press, Inc., New York, 1968). 
35. Zetterström. R., and Ernster, L.: Bilirubin, an uncoupler of oxidative phosphorylation in isolated mitochondria. Nature (Lond.), 178: 1335 (1956).

36. Requests for reprints should be addressed to: Peter F. Whitington, M.D., Department of Pediatrics, University of Tennessee Center for the Health Sciences, 550 Dobbs Research Institute, Memphis, TN 38163 (USA).

37. This research was supported by HD-05533, AM-21668, and AM-13927 from the
National Institutes of Health, by Veterans Administration Research Funds, by

RR-05432-PFW from the United States Public Health Service, and by New

Faculty Grant H-00039 from the University of Tennessee Center for the Health Sciences.

38. Received for publication July 29,1980

39. Accepted for publication October 28, 1980. 